DOI 10.37882/2223-2982.2021.09.06

\title{
ПРЕДПОСЫЛКИ ОБРАЗОВАНИЯ КОММУНИСТИЧЕСКОЙ ПАРТИИ КИТАЯ. ЕЕ ОБЩИЕ И ОТЛИЧИТЕЛЬНЫЕ ЧЕРТЫ С РОССИЙСКОЙ СОЦИАЛ-ДЕМОКРАТИЧЕСКОЙ РАБОЧЕЙ ПАРТИЕЙ (БОЛЬШЕВИКОВ)
}

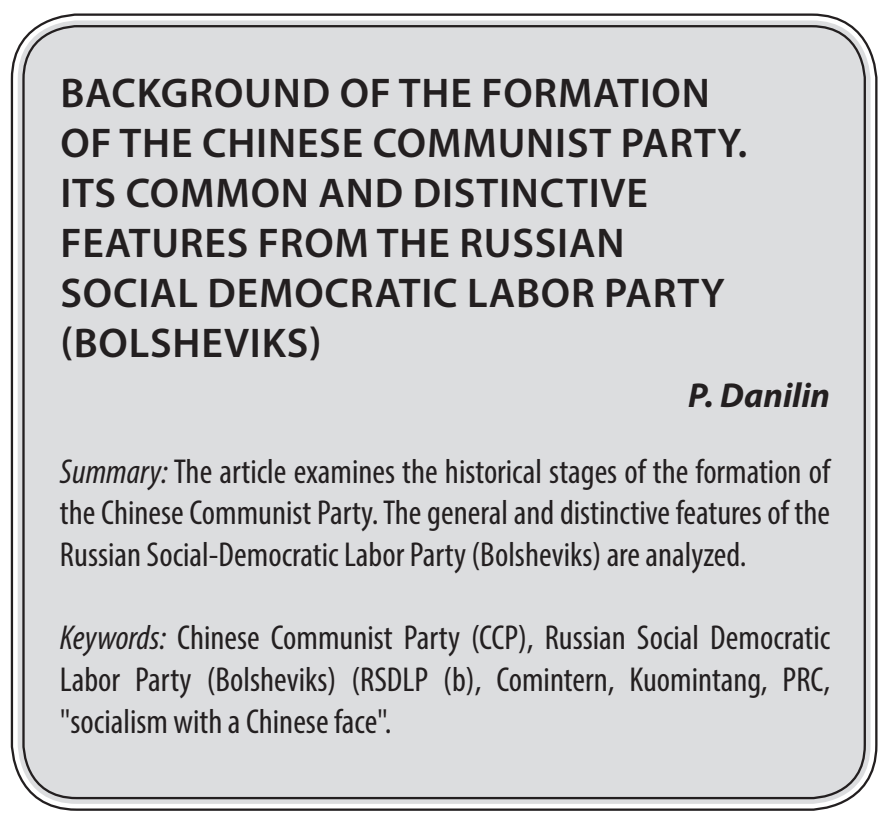

$\Pi$ обеда Советской России в Гражданской войне активизировала мировое революционное движение во всём мире, в том числе и на Дальнем Востоке. Инициировал этот процесс III Интернационал, созданный на его 1-м Конгрессе в марте 1919 г. в Москве с участием 52-х делегатов от 35-ти организаций 21-й страны, представителей угнетённых народов Ирана, Турции, Кореи и Китая. Коммунистическая партия Китая создавалась на базе революционных групп, созданных китайской интеллигенцией. 1-й организационный съезд китайских коммунистов состоялся в Шанхае летом 1921 г. с участием 12 делегатов от коммунистических ячеек, представителей Дальневосточного отделений 3-го Коминтерна. Руководителем КПК был избран Чэнь Дусю, являвшийся по своим политическим взглядам демократ-радикалом. В 1922 г. на своём II съезде, по примеру российских социал-демократов начала XX века, китайские коммунисты приняли Манифест, определивший программу-минимум (свержение иностранных милитаристов и достижение полной независимости Китая, создание демократической республики) и программу-максимум (строительство в Китае социализма и коммунизма). Первоначально, китайские коммунисты входили в состав партии Гоминьдан, созданной Сунь Ятсеном. Единая революционная партия была образована в сентябре 1922 г. 1 января 1923 г. Сунь Ятсен объявляет декларацию объединения пар-
Данилин Петр Николаевич Аспирант, Крымский федеральный университет им. В.И. Вернадского oknavi2007@gmail.com

Аннотация: В статье рассмотрены исторические этапы образования Коммунистической партии Китая. Проанализированы общие и отличительные черты с Российской социал-демократической рабочей партией (большевиков).

Ключевые слова: Коммунистическая партия Китая (КПК), Российская социалдемократическая рабочая партия (большевиков) (РСДРП (б), Коминтерн, Гоминьдан, КНР, «социализм с китайским лицом».

тий с целью строительства независимого единого Китая, борьбы против японско-империалистического гнёта и феодально-компрадорских кланов. Военные кадры для Национальной армии китайских коммунистов готовила Военная школа Ванпу в Кантоне, а национальной интеллигенции - Коммунистический университет имени Сунь Ятсена в Москве. В 1920-е годы в Китае велись непрерывные гражданские войны различных кланов. В 1927 г. Гоминьдан разорвал союз с КПК и начал свой этап борьбы за власть во главе с Чан Кайши. Внутриполитическая борьба в Китае обострилась. В 1931 г. китайские коммунисты создали в провинции Изякси Советскую Республику, имевшую более чем 300-тысячную Красную армию. С 7 июля 1937 г. в Китае началась война с японскими захватчиками. Она носила, в основном, партизанский характер и привела к созданию Особого района, освобожденного от японцев, от гоминдановцев.

Разгром Красной Армией Квантунской армии милитаристской Японии позволил китайским коммунистам решить проблему борьбы с иностранными интервентами. За этим этапом последовала гражданская война с Гоминьданом и армией Чай Кайши, войска которого были разгромлены. Остатки их эмигрировали на остров Тайвань, где объявили о создании своей части китайского государства. 1 октября 1949 г. в Пекине провозглашает- 
ся Китайская Народная Республика (КНР), политическим руководителем которой стала Компартия Китая во главе с Мао Цзэдуном. По примеру СССР и КПСС, она начала строительство своего независимого государства с переходного периода, основными элементами которого по образцу советского НЭПа 1920-х стали:

- национализация имущества иностранного капитала и компрадорской китайской буржуазии; создание структур государственного имущества и банковской системы;

- проведение широкой кооперации промышленного производства, в которую, в отличие от СССР, была вовлечена национальная буржуазия, ремесленничество, все слои китайских торговцев;

- широкая кооперация аграрного сектора экономики, составляющей подавляющую её часть, причём в отличие от КПСС и советского государства, она также носила всеобъемлющий характер с охватом всех категорий сельских жителей;

- основой китайских аграрных коммун стали производственные бригады - хозрасчётные объединение, распространявшиеся на всю деревню с сохранением приусадебных участков членов коммун;

- переход от феодально-капиталистического общества к строительству китайского социализма при активной помощи Советского Союза.

Для решения этих задач Мао Цзэдун совершил поездку в Москву, где имел две встречи с И.В. Сталиным: 1-ая состоялась 16 декабря 1949 г. на Кущевской даче, 2-я - 22 января 1950 г. Итогом этих встреч стало:

- подписание Договора о дружбе, союзе и взаимной помощи КНР и СССР от 14 февраля 1950 г.;

- заключение соглашения о предоставлении Китаю кредита на 300 млн. долларов для оплаты поставок из СССР оборудования и материалов для новой китайской промышленности;

- подписание соглашений о Китайско-Чаньгуньской железной дороге, о Военно-морской базе в Порт-Артуре и порте Дальний.

За 1950-1959 гг. Советский Союз участвовал в восстановлении и строительстве свыше 400 китайских промышленных предприятий и цехов, строительстве 160 китайских заводов ВПК. Всего на эти и другие цели СССР выделил КНР 1 млрд. 816 млн. инвалютных рублей под 2\% годовых. Погашение кредита шло китайскими товарами народного потребления. В 1949-1960 гг. в Китае работало около 10 тыс. советских специалистов. За этот период в СССР прошло обучение около 1 тыс. китайских учёных, 11 тыс. студентов и аспирантов, 10 тыс. инженеров, техников и рабочих. Процесс взаимовыгодных советско-китайских отношений того времени нашел своё отражение в сборнике документов [17]. За этим периодом взаимного сотрудничества наступило время охлаждения, а затем и полного разрыва всех форм политических, экономических, военных, идеологических и культурных отношений. Специалисты возлагают вину за это на Н.С. Хрущёва, его личное негативное отношение к Мао Цзэдуну. Ситуацию резко обострила «культурная революция» в Китае в 1966-1976 гг. Смерть Мао Цзэдуна в сентябре 1978 г. привела к обострению борьбы политических кланов в партии и государстве.

Поворотным в политической истории КНР стал декабрьский (1978 г.) Пленум ЦК КПК 11 созыва. Новым организатором социалистического строительства с «китайским лицом» выступил Дэн Сяопин (1904-1997). Суть концепции его реформ была опубликована в постсоветской России [11]. Одной из центральных его идей стала программа конвергенции (единения) плановой социалистической китайской экономики с развитием рыночного хозяйства под руководством КПК. С 1990 г. теория строительства «социализма с китайской спецификой» была принята в качестве государственной идеологии и вписана в Конституцию КНР как «специфический китайский социализм». Данный этап китайской модернизации рассмотрен, в частности, в работе А.В. Виноградова [7]. В последующие годы КПК продолжала проведение этой политики, что закрепил в 1999 г. XIV съезд партии. К этому времени КПСС и руководимое ей советское государство ушли с политической арены.

Анализ хода строительства «социализма с китайской спецификой» был сделан на XVI съезде КПК в 2003 г., документы которого были опубликованы в Пекине на русском языке [10]. На съезде выдвигалась задача строительства в Китае «среднезажиточного общества» (сяокан). В процессе строительства этого общества КПК вывела КНР на 2-е место в мире по уровню экономического развития после США. Одним из решающих факторов, позволивших добиться столь высоких результатов, стала реализация лозунга «Одно государство - две системы». Суть его состоит в реализации 2-х ценностных систем: 1-я - «базовые ценности социализма» (государства и КПК); 2-я - «общественные ценности» (личная свобода, демократия, соблюдение прав человека и др.). Ключевыми социалистическими ценностями были определены следующие комплексы:

- социалистическое государство, его богатство и мощь, демократия, цивилизованность и гармония;

- социалистическое общество, равноправие, справедливость, верховенство закона;

- на личностном уровне: патриотизм, преданность работе, честность, дружелюбие.

Особое место в этом комплексе отводилось КПК как сакральной части политической составляющей китайского общества, отражающей государственные интересы страны. Новой политической моделью КПК компар- 
тия определила «консультативный социализм» из пяти отличительных черт:

- максимальная сосредоточенность на удержании власти и исключение гегемонии КПК;

- совершенствование управления как внутри партии, так и в государственном аппарате;

- достижение способности улавливания изменений в общественном мнении, реагирование на него и исправление;

- поддержка темпов роста и развития экономики целесообразными способами;

- выдвижение знамени национализма как единственной национальной гордости истории цивилизации Китая с величием КНР под руководством КПК.

КПК определила следующие генеральные направления укрепления своей руководящей роли в обществе и государстве:

- укрепление связи с народными массами, улучшение жизни крестьян, проведение политики социальной справедливости;

- институализация, внедрение и усиление правопорядка под девизом «Власть при помощи закона», для чего её аппарат доведен до 200 тыс. судей, 160 тыс. прокуроров, 150 тыс. адвокатов. Во главе аппарата правопорядка стал Верховный Народный Суд.

- национальная сплочённость вокруг КПК и её руководства, определение государственной идеологии насаждения национализма.

XVIII съезд КПК избрал Генеральным секретарём КПК в ноябре 2012 г. Си Цзиньпина, определил две главные цели 100-летних юбилеев в партии и государстве:

1. посторенние к 2021 г. «среднезажиточного общества и ликвидация бедности» (к 100-летию КПК);

2. превращение КНР в «полностью развитую и передовую страну» к 2049 г. (100-летие образования KHP).
Решение этих 2-х главных целей определялось как «достижение китайской мечты». XIX съезд КПК, проведенный в октябре 2017 г., дал анализ строительства социализма в стране, выделив следующие его этапы:

- «социализм 1.0»- модель, заимствованная у КПСС 1949-1979 гг.;

- «социализм 2.0» - социализм с китайской спецификой (1979-2017 гг.);

- «социализм 3.0» - модель, когда страна приступила к строительству социализма в эпоху развития высоких технологий и ужесточения международной экономической конкуренции, прежде всего с США.

Итак, оценивая черты современного этапа строительства КПК, возможно констатировать:

- сохранение её руководящей роли в обществе и государстве;

- продолжение политики строительства социализма с учетом реалий XXI века;

- постоянное реформирование политической системы общества с учётом уроков прошлого, функционированием в государстве 8 политических партий во главе с КПК:

1. Революционный комитет Гоминьдана;

2. Демократическая лига Китая;

3. Ассоциация демократического национального строительства Китая;

4. Ассоциация содействия развитию демократического Китая («Миньцзинь»;

5. Рабоче-крестьянская партия Китая;

6. Китайская партия стремления к справедливости («Чжугундан»);

7. Общество «3 сентября» («Цзюсань»);

8. Лига демократической автономии Тайваня.

Таким образом, современная политика КПК по строительству социализма в КНР носит многовекторный как внутри-, так и внешнеполитический характер.

\section{ЛИТЕРАТУРА}

1. Абрамова Н.А. Политическая культура Китая: традиции и современность / Н.А. Абрамова. - М.: Муравей, 2001. - 318 с.

2. Авдокушин Е.Ф. Теоретические основы экономической реформы в КНР / Е.Ф. Авдокушин. - М.: изд-во ВЗПИ: АО «Росвузнаука», 1991. - 215 с.

3. Асалханова 0.Д. Китайская интеллигенция в условиях модернизации общества: Последняя четверть XX в.: диссертация кан. социологич. наук: спец. 22.00.04 / Асалханова Оксана Дмитриевна. - Улан-Удэ, 2003. - 152 с.

4. Барышев А.П. КНР: стратегия социализма (исторический опыт и особенности современного этапа) / А.П. Барышев. - М.: ГУП М0, $2004 .-201$ с.

5. Бородич В.Ф. Проблемы трансформации политических систем России и Китая (конец XX - начало XXI вВ.) : опыт сравнительного анализа / В.Ф. Бородич. - М.: ИДВ РАН, 2008. - 247 c.

6. Васильев А.С. Культура, религии, традиции в Китае / А.С. Васильев. - М.: Ломоносов, 2015. - 517 с.

7. Виноградов А.В. Китайская модель модернизации: поиски новой идентичности / А.В. Виноградов. - М., 2008. - 363 с.

8. Вознесенский А.Д. Китай и Россия в Евразии: историческая динамика политических взаимовлияний / А.Д. Вознесенский. - М.: Муравей, $2004 .-600$ с.

9. Девять комментариев о Коммунистической партии: сборн. стат. междунар. изд. проекта «Великая эпоха» / [пер с англ.]. - М.: Красный пролетарий, 2005. $-220 \mathrm{C}$. 
10. Документы XVI Всекитайского съезда КПК. - Пекин, 2003. - 217 с.

11. Дэн Сяопин. Строительство социализма с китайской спецификой / Сяопин Дэн. - М., 1997. - 497 с.

12. Киссинджер Г. О Китае / Г. Киссинджер. - М.: Изд-во «АСТ», 2013. - 635 с.

13. Китай: угрозы, риски, вызовы развитию / [под ред. В. Михлеева]. - М.: Московский центр Карнеги, 2005. - 647 с.

14. КНР 55 лет: политика, экономика, культура. - М.: ИДР РАН, 2004. - 494 с.

15. Мамаева Л.М. Партия и власть: компартия Китая и проблемы реформы политической системы / Л.М. Мамаева. - М.: Русская панорама, 2007. - 232 с.

16. Отечественная историография КНР. Некоторые направления: сборн. стат. / Российская акад. наук, Ин-т Дальнего Востока; [под ред. Н.Л. Мамаевой, И.Н. Сотниковой]. - Москва: Наука - Восточная лит., 2015. - 260 с.

17. Советско-китайские отношения. 1917-1957: сборн. докум. / [отв. ред. И.Ф. Курдюков [и др.]; [Акад. наук СССР. Ин-т китаеведения]. - М.: Изд-во вост. лит., 1959. -467 c.

18. Тихвинский С.Л. Мемуарная литература по истории советско-китайских отношений (1939-1950гг.) / С.Л. Тихвинский // Новая и новейшая история. - 2007. - №3. - С. 109-126.

19. Цзян Изэминь. 0 социализме с китайской спецификой: сб. высказываний по темам / Цзэминь Цзян; [пер. с кит.: Ю.М. Галенович]. - М.: ИДЛ РАН, 2002. $24 \mathrm{c}$.

(с Данилин Петр Николаевич (oknavi2007@gmail.com).

Журнал «Современная наука: актуальные проблемы теории и практики»

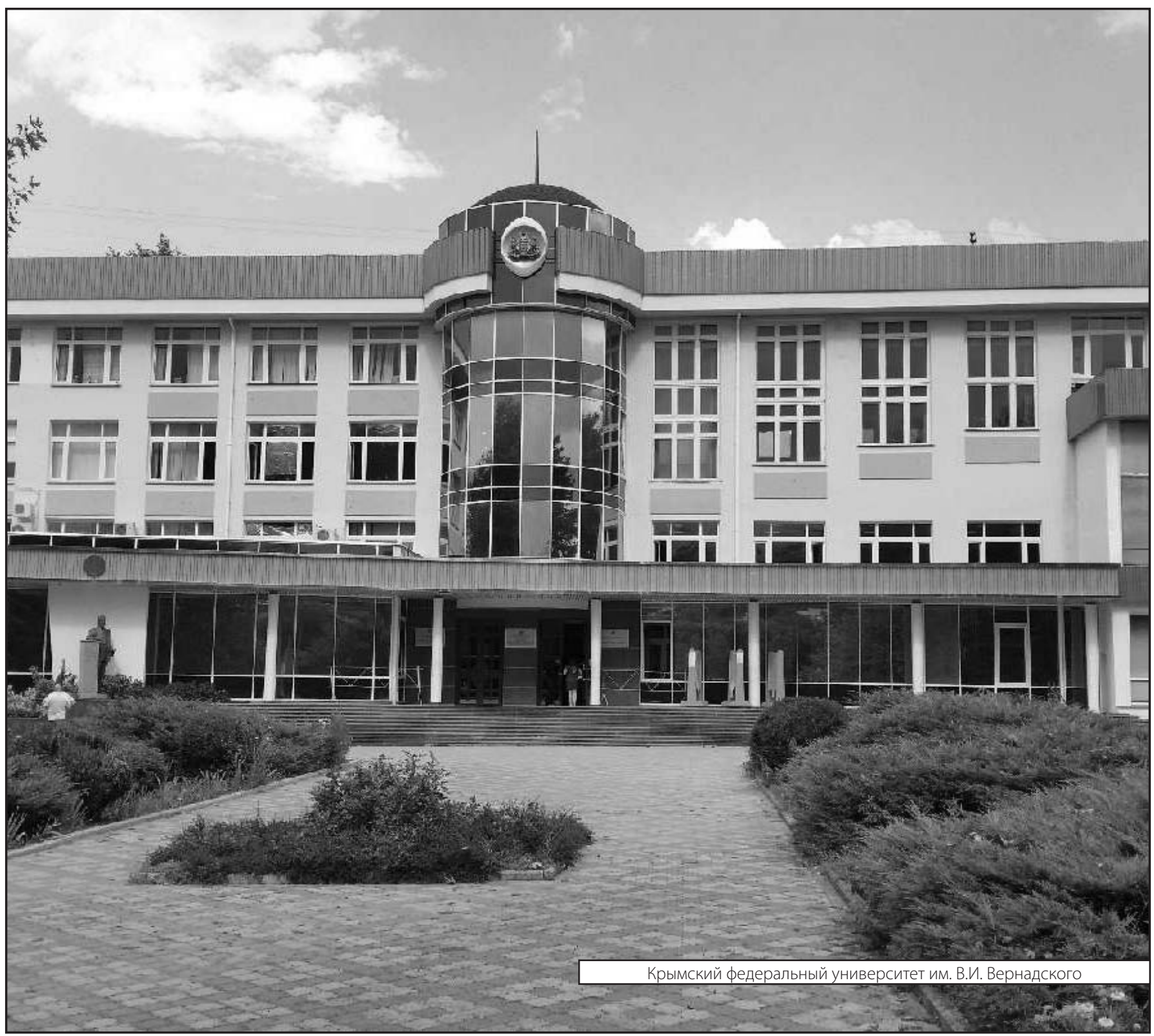

